\title{
Market strategies in two major companies in Mexico: Bachoco and Lala
}

\section{Estrategias mercadológicas en dos grandes empresas de México: Bachoco y Lala}

\author{
BALLESTEROS-AUREOLES, Alejandra†** TLACUILO-GONZÁLEZ，José Antonio, Zavala- \\ Ramírez, María Esther and Jiménez-Calvo, María de Lourdes
}

Universidad Tecnológica de Nezahualcóyotl, Circuito Universidad s/n, Rey Neza, 57000 Nezahualcóyotl, Méx.

ID $1^{\text {st }}$ Author: Alejandra, Ballesteros-Aureoles

ID $1^{\text {st }}$ Coauthor: José Antonio, Tlacuilo-González

ID $2^{\text {nd }}$ Coauthor: María Esther, Zavala-Ramírez

ID $3^{\text {rd }}$ Coauthor: María de Lourdes, Jiménez-Calvo

DOI: $10.35429 /$ JGE.2019.4.3.5.15

Received February 17, 2019; Accepted June 25, 2019

\begin{abstract}
During 70 years of existence, two companies have been studied historically and economically, serve as examples for the business sector and the Mexican food industry, as other companies have had boom and declining stages, but today they are a example; have been observed in them the different administrative and market strategies, which they have used, is how the objective of this research work is to identify and analyze the different market strategies, specifically the Mix Marketing variables that Bachoco and Lala companies have used throughout their history. Bachoco who was born in 1949, (Ceruti, M.; Hernandez, M.C.; Marichal, C., 2010), considered the largest poultry producer in Mexico, the owners of the Robinson Bours family, this company is reviewed by authors such as Hernández, M.M. del C. \& Vázquez, R.M.A. (2010), while Lala is another large company in northern Mexico, converted in the largest producer of fresh milk in the country, which was born in 1949, says Rivas, S.E. (2010). This research is descriptive in a qualitative type, since the results are not quantified, the documents generated by other investigations, considered as secondary sources and the documents of the same companies, are reviewed, as primary sources. The results present the variables found from Mix Marketing, product, price, square and promotion, for both companies. The findings are to show that the theory is applicable to practice, and because companies use an excellent combination of market variables, a mixture of variables, which have allowed them to operate in the market, to meet the objectives and goals of the marketing such as: giving end-consumer satisfaction, increasing demand and supply, having a brand value, among other business profits.
\end{abstract}

\begin{abstract}
Resumen
Durante 70 años de existencia, dos empresas han sido estudiadas desde puntos de vista históricos y económicos, sirven de ejemplos para el sector empresarial y la industria alimentaria mexicana, como otras empresas han tenido etapas de auge y declive, pero hoy por hoy son un ejemplo; se han observado en ellas las diferentes estrategias tanto administrativas como mercadológicas, que han utilizado, es así como el objetivo de este trabajo de investigación consiste en identificar y analizar las diferentes estrategias mercadológicas, específicamente las variables del Mix Marketing que las empresas Bachoco y Lala han utilizado a lo largo de su historia. Bachoco que nació en 1949, (Ceruti, M.; Hernández, M. C.; Marichal, C., 2010), considerada la mayor productora avícola de México, los dueños la familia Robinson Bours, esta empresa es revisada por autores como Hernández, M.M. del C. \& Vázquez, R.M.A. (2010), mientras que Lala es otra gran empresa del norte de México, convertida en la mayor productora de leche fresca del país, que nació en 1949, nos dice Rivas, S.E. (2010). La presente investigación es de tipo descriptiva con enfoque cualitativo, ya que no se cuantifican los resultados, se revisan los documentos generados por otras investigaciones, considerados como fuentes secundarias y los documentos de las mismas empresas, como fuentes primarias. En los resultados, se presentan las variables encontradas del Mix Marketing, el producto, precio, plaza y promoción, para ambas empresas. Las conclusiones son mostrar que la teoría es aplicable a la práctica, y como las empresas utilizan una excelente combinación de variables mercadológicas, mezcla de variables, que les han permitido operar en el mercado, para cumplir con los objetivos y las metas de la mercadotecnia como son: dar una satisfacción al consumidor final, aumentar la demanda y oferta, tener un valor de marca, entre otras ganancias empresariales.
\end{abstract}

Estrategias Mercadológicas, Bachoco, Lala

Citation: BALLESTEROS-AUREOLES, Alejandra, TLACUILO-GONZÁLEZ, José Antonio, Zavala-Ramírez, María Esther and Jiménez-Calvo, María de Lourdes. Market strategies in two major companies in Mexico: Bachoco and Lala. RINOE Journal-General Economics. 2019. 3-4: 5-15.

\footnotetext{
* Correspondence to Author (email: aureoles71@yahoo.com.mx)

$\uparrow$ Researcher contributing first author.
} 


\section{Introduction}

With the experience in the review of different companies, regarding their economic activities, we found the relevance of knowing the strategies in question of marketing that Mexican companies have carried out, because they serve as an example to specifically perform the theoretical concepts, which They are put into practice, which serve not only as an example, but also provide extensive learning, because the objective of this research work is to identify and analyze the different marketing strategies, specifically the Mix Marketing variables that companies Bachoco and Lala have used throughout their history. Bachoco, born in 1949, (Ceruti, M .; Hernández, M. C .; Marichal, C., 2010), considered the largest poultry producer in Mexico, the owners of the Robinson Bours family, this company is reviewed by authors such as Hernández, M.M. del C. \& Vázquez, R.M.A. (2010), in the annual report of the company, it is specified that it was until 1952, when they consider it as the year in which it was born in the State of Sonora, Mexico, and is officially constituted as Industrias Bachoco, S.A.B. de C.V., on April 17, 1980, with an indefinite duration. The Company is commercially known as Bachoco. (Bachoco, 2017). While Lala is another large company that also emerged in northern Mexico, which has become the largest producer of fresh milk in the country, Rivas, S.E. (2010).

Lala began operations in 1949, in La Laguna, when a group of farmers joined forces, in order to carry out the process of pasteurization and marketing of milk from milk producers in $\mathrm{La}$ Laguna, Grupo LALA, S.A.B. de C.V., was incorporated in Torreón, Coahuila, on November 1, 1984, under the name "Grupo Industrial Lala, S.A. of C.V. ", in accordance with the Law of Commercial Companies, with a duration of 99 years. (Lala, 2018). In this quest to order and show their history, their economic development and business strategies and marketing strategies, since marketing is one of the most recent functions that companies replaced in their organizational charts, where they used the areas or departments within, possibly of administration management, such as sales.

\section{Marketing or Marketing}

When reviewing the Marketing concept, it is considered to use the Marketing and Marketing concept interchangeably; as a Marketing translation, the word Marketing. For authors such as Kotler (2018), AMA (2018), they use the term Marketing, while in Mexico Fischer (2017), Saldaña (1999), Saldaña \& Cervantes (2000), they use Marketing.

Each author has his own definition mentioned Kotler and Keller (2006), cited by Bur (2014), Marketing is an integrative, proactive discipline, aimed at meeting the needs of target audiences. So the purpose of Marketing is to obtain mutual benefits, satisfaction of the needs of a target audience and benefits for the organization. Organizations seek to meet the needs of consumers by presenting a value proposition that is specified in an offer of goods or services. Consumers choose one of the different offers that organizations present based on the value they perceive. (p.47). While the American Marketing Association (1985), who provides one of the most precise definitions, defines Marketing as a set of processes to create, communicate and deliver value to customers and manage customer relationships, so that they benefit The organization and its shareholders. (AMA, 2019).

This is how the Marketing concept highlights the words satisfaction of needs, value, consumers or customers, companies or organizations, product, price, place, promotion. A fundamental concept is that of strategies, of which those that are mainly used in marketing is the so-called Mix Marketing or Marketing Mix, which is known as the 4 p's.

For Mercado (2008), market strategies are plans designed to select the various businesses in which a company could be. These strategies identify the markets that should be served and the line of products and services that should be generated based on an evaluation of the company's environment, resources and objectives. Within the marketing strategies, Mix Marketing is considered, which is known as Marketing Mix, as the set of the 4 p's, is the complete offer that the organization offers its consumers a product with its price, your place and your promotion. 
Today it is a common practice in all types of organizations to raise their marketing efforts around 4 p's. Therefore, it is considered that marketing must achieve and maintain a marketing mix that provides the market with greater satisfaction than those offered by competitors. In addition, the financial results of an organization are based on how powerful its marketing mix is.. (Fischer \& Espejo, 2017).

\section{Background}

E. Jerome Mc Carthy is acknowledged, having conceptualized it in his Basic Marketing: A Managerial Approach, it is also said that the term was used by Neil Borden, in an article called "The Concept of The Marketing Mix", which is published in The Journal of Advertising Research in 1984. There are those who consider that the 4 p's are insufficient for all businesses, so, in 1981, Dick Berry, developed his book "Industrial Marketing for Results" added the "s "Of services.

\section{Product, Price, Place, Advertising and Sales Promotion}

The product, is the first of the 4 p's, is the set of attributes and qualities, tangible, such as presentation, packaging, design, content, and intangibles, such as brand, image, service and added value, which the customer accepts To meet your needs and desires. Classification of products, according to Kotler, there are nondurable goods, which are those tangibles that are normally consumed in one or a few uses, the durable goods, are those tangible goods that normally survive many uses, and the services, which are activities, benefits or satisfactions offered for sale. Among the types of consumer goods, are the products of convenience, comparison, specialty, unwanted, seasonal, high and medium turnover, perishable. (Münch, Sandoval, Torres, \& Ricalde, 2012).

Within the product, the 4 e's are known, which form it, the container, the packaging, the packaging and the label, which allow the product to be identified, since the consumer recognizes it by its container and packaging, being in the retail stores, perceives the brand and strengthens the well-known brand value, also comes close to reading the label, to recognize if the product meets the specifications and / or requirements you need.
The second $\mathrm{p}$, is known as the Price, which is defined as the monetary value of a product or service. The determination of the price depends on the objectives of the organization and its position in the market, there are different types of price, geographical, unique, variable, introduction, penetration, line, status or prestige. While the basic criteria to determine the price are: economic, market, psychological, opportunity, selection or introduction, delivery, geographical, controlled, marginal analysis, skimming, list, base, factory, promotional, segmented, wholesale retail, seasonal, uniform. (Münch, Sandoval, Torres, \& Ricalde, 2012).

The third p, called plaza, also known as distribution, becomes an aspect of logistics. The purpose of the distribution is to position the product in the most appropriate place and time for the product and / or service to be available. The selection of distribution points and channels depends on the resources, as well as the specific characteristics of the product and the target market towards which the marketing mix is directed. The square is the physical place where a product is offered. For this there is a whole plan to send the item from the place of manufacture to the place of consumption. Just in time is used for the logistics strategy, virtual warehouses, containers, clusters or clusters, distribution or logistics systems represent a basic element in marketing; The different types of distribution are: intensive, selective and physical. Another element of the distribution are the so-called distribution channels, they are the routes of the product from its origin or production to the final customer. (Münch, Sandoval, Torres, \& Ricalde, 2012).

Four basic distribution channels are known, the zero channel, which is a direct channel because there are no intermediaries, channel one, has an intermediary, which is a retailer or retailer, channel two, has two intermediaries, a wholesaler and a Retailer, and Channel Three, has a sales agent, a wholesaler and a retailer. The intermediary, is that company or person, which contributes to the product distribution process. 
Finally, the $4 \mathrm{p}^{\prime} \mathrm{s}$, is called promotion, which is divided into advertising and sales promotion. There is also the concept of Mix promotes, which includes sales, advertising, packaging, sales promotion, public relations, merchandising and other elements of promotion support. Here advertising and sales promotion are defined only. It is observed in scheme 1.

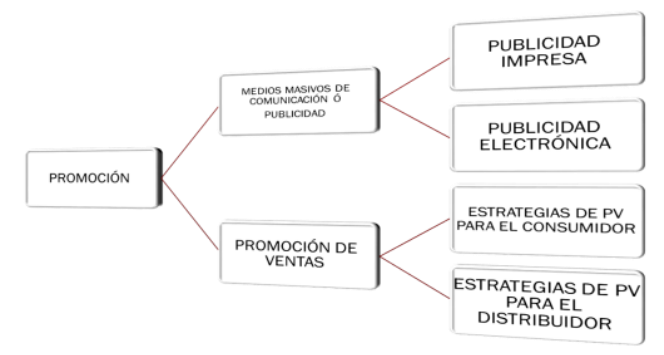

Figure 1 Promotion

Source: own elaboration with data from (Fischer \& Espejo, 2017)

Advertising comes from the Latin publicare, which means exhibiting in the public square available to anonymous passersby. Advertising is a persuasive and direct communication action that is produced and planned regularly and carried out through the media.

That is, advertising is any form of public and impersonal communication whose purpose is to influence perceptions in consumer behavior to induce the purchase decision, its objective is to influence, create and establish in the consumer's mind a permanent perception of The quality and benefits of the product.

There are an infinite number of types of advertising, to mention are the undifferentiated, associated, collective, commercial, demonstrative, expectations, exterior, general, graphic, free, printed, indirect, informative, institutional, brand, mechanistic, prestigious, private, subliminal, of product. (Münch, Sandoval, Torres, \& Ricalde, 2012).

In advertising, the most used elements are, the design of a logo and slogan, which help to create a brand, with the idea of converting it into a registered brand, to create its brand value, this will be used in all advertising that be used It is observed in scheme 2 .

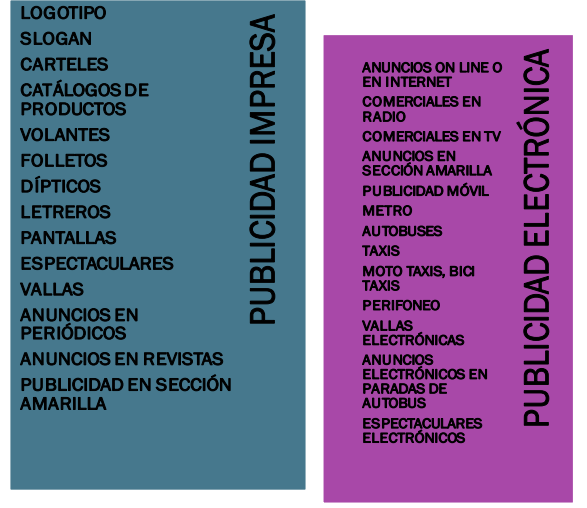

Figure 2 Advertising

Source: own elaboration with data from (Fischer \& Espejo, 2017)

Sales promotion is the activity of marketing that aims to stimulate the sale of a product personally and directly through a regular and planned process with mediated results and allows through prizes, demonstrations, exhibitions, etc., that the Consumer and seller get an immediate benefit of the product. There is a sales promotion for the consumer, it is about motivating the customers' desire to buy so that they acquire a product or service. Strategies for merchants and distributors. they are used to stimulate resellers to work and aggressively market a specific product. It is observed in scheme 3.

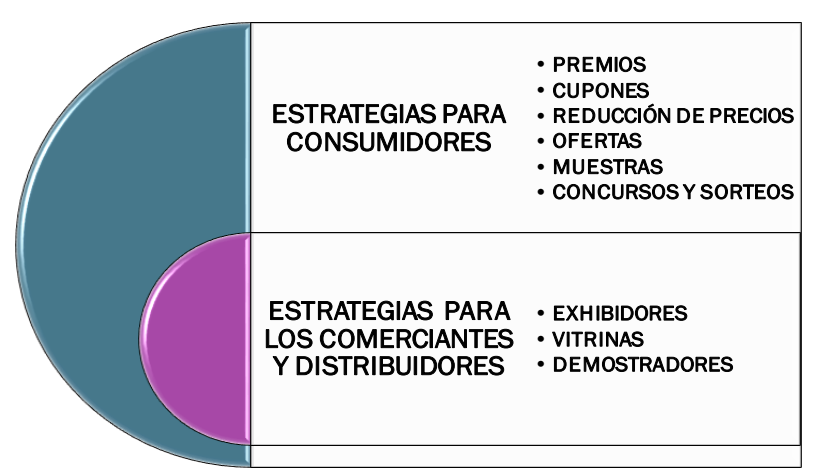

Figure 3 Sale promotion

Source: own elaboration with data from (Fischer \& Espejo, 2017)

\section{Problem Statement}

It is not enough for the management of the company to know that its activities must be focused on the client, as it must also know what to do, and how to achieve this satisfaction. In this way, the company will present a main question: How to achieve customer satisfaction based on the resources and objectives of the company if the elements that constitute the marketing mix, the Mix Marketing or the $\mathrm{p}$ 's ?. (Canedo \& Barajas, 2004). 
Likewise, a series of questions that arise in this regard must be answered: (Canedo \& Barajas, 2004).

- Is the market known and which with the opportunities he presents for the company?

- Can you produce or offer the good or service that the market requires, do you have the capacity?

- What are the characteristics of the good or service that customers are looking for?

Having identified the needs of the market and knowing that these needs can occur, it is necessary to raise other questions:

- How will it be marketed in the market?

- What will be your design, your packaging, your label?

- Can you produce or offer at prices that potential customers are willing to pay and thus compete with the market?

- Do you have a projection of the product life cycle, do you have a new product development strategy?

- What is the most appropriate distribution for what is produced and offered?

- Should one or more of its own points of sale be opened or marketed through third parties?

- Do you have the physical, financial and logistical capacity to store, distribute, and market the products?

- How will you promote the product or service?

-Where are the potential customers?

- Can you reach them directly?

- Can mass media be used to publicize the product or service?

- How much will the acquisition of each client cost?
The answers to these questions help to establish clear, realistic and well defined strategies in each area of the organization in such a way that the marketing strategy, the finance strategy, the production strategy, among others. establish synergy and generate a competitive advantage in relation to other companies, as a common factor of various companies is that they do not operate with adequate plans for their markets. (Canedo \& Barajas, 2004). The strategies are the foundation to carry out a correct direction and execution of the plans, goals and programs established to meet the objectives of the company and thus remain at the forefront and establish leadership in the sector where it is located the company as a result of correct decision making. Because a growing percentage of the business environment is based on a marketing scheme; Marketing strategy is extremely important to achieve the objectives. (Canedo \& Barajas, 2004).

\section{Overall objective}

The objective of this research work is to identify and analyze the different marketing strategies, specifically the Mix Marketing variables that the Bachoco and Lala companies have used throughout their business history.

\section{Methodology}

The present investigation is descriptive with a qualitative approach, since the results are not quantified, the documents generated by other investigations, considered as secondary sources and the documents of the same companies, as primary sources are reviewed.

This research paper identifies and analyzes the elements that constitute the marketing mix, that is, the set of marketing variables controllable by the company (product, price, place, promotion), applying each of the 4 p's in the Bachoco companies and Lala, highlighting how the optimal combination of them establish an essential strategy that allows to achieve a competitive advantage to obtain a positioning of the company's products with respect to its potential competitors. 


\section{Results}

\section{Application of Mix Marketing to companies Grupo Bachoco S.A.B de C.V. and Grupo Lala S.A.B de C.V.}

As mentioned in the research methodology used for this purpose, it is descriptive with a qualitative approach, since this research develops a representation or image of the phenomenon studied from its variables.

Therefore, it does not quantify results, circumscribing itself in the elements that integrate the marketing mix.

Although the elements of the marketing mix are linked, for didactic purposes each one is analyzed separately, sized according to the characteristics of the research. In the results, the variables found in Mix Marketing, the product, price, place and promotion for both companies are presented.

The conclusions are to show how the theory is applicable to practice, and how companies use an excellent combination of marketing variables, mix of variables, which have allowed them to operate in the market, to meet the objectives and goals of marketing as

They are: giving satisfaction to the final consumer, increasing demand and supply, having a brand value, among other business profits.

\begin{tabular}{|c|c|}
\hline Strengths & Opportunities \\
\hline $\begin{array}{l}\text { S1. Its main strength has } \\
\text { been its ability to adapt to } \\
\text { consumer preferences and } \\
\text { internal market trends. } \\
\text { S2 It established a policy of } \\
\text { using own resources as the } \\
\text { main source of financing for } \\
\text { its expansion. } \\
\text { S3 Its high marketing } \\
\text { percentage (53\%) belongs } \\
\text { to the fresh produce } \\
\text { segment without any } \\
\text { processing. } \\
\text { S4 Its inputs are mainly } \\
\text { based on cereals and pasta } \\
\text { that represent } 60 \% \text { of its } \\
\text { production costs. } \\
\text { S5 The location of the } \\
\text { industry with respect to the } \\
\text { producing areas or the main } \\
\text { circuits of international } \\
\text { trade are decisive for the } \\
\text { company to be competitive. } \\
\text { S6 In } 1992 \text {, they } \\
\text { implemented an advanced } \\
\text { control and management } \\
\text { system that synchronized } \\
\text { the operation of the } \\
\text { complexes. }\end{array}$ & $\begin{array}{l}\text { O1. He has been able to } \\
\text { locate and establish his } \\
\text { plants in strategic places, } \\
\text { he has had the vision to } \\
\text { take advantage of those } \\
\text { places. } \\
\text { O2 The domestic market } \\
\text { has been his great } \\
\text { opportunity. } \\
\text { O3 In the 60s, chicken } \\
\text { consumption grew, which } \\
\text { came to represent } 50 \% \text { of } \\
\text { meat products and } 100 \% \text { of } \\
\text { egg products. The increase in the } \\
\text { O4 The (in the } \\
\text { minimum wage (thime } \\
60 \text { s), allowed to increase } \\
\text { the consumption of these } \\
\text { products. } \\
\text { 05. In the 90s. there was an } \\
\text { internal restructuring of } \\
\text { poultry farming, } \\
\text { stimulated by the chicken } \\
\text { meat industry. } \\
\text { 06. Changes in the } \\
\text { operational structure, in } \\
\text { 1999, established the } \\
\text { Enterprise Resource } \\
\text { Planning (ERP) system, } \\
\text { SAP R / } 3 \text {, to simplify the } \\
\text { management of the } \\
\text { production chain and } \\
\text { monitor the markets. } \\
07 . \text { Strategic acquisitions. }\end{array}$ \\
\hline WEAKNESSES & THREATS \\
\hline $\begin{array}{l}\text { W1 Its main inputs, cereals, } \\
\text { oilseeds, breeding grounds, } \\
\text { biochemicals, were } \\
\text { imported. There were } \\
\text { international prices, plus } \\
\text { hospitalization costs. } \\
\text { W2 Due to external factors, } \\
\text { it has to endure in the 70s., } \\
\text { A growing demand, lower } \\
\text { production costs, excess } \\
\text { supply, imbalance in prices } \\
\text { and a government policy } \\
\text { that would no longer } \\
\text { support production, but to } \\
\text { contain inflation it would be } \\
\text { through price control, in } \\
\text { products of the basic basket. }\end{array}$ & $\begin{array}{l}\text { T1 In the beginning the } \\
\text { company suffered a } \\
\text { saturation of the Sonoran } \\
\text { poultry market of final } \\
\text { products. } \\
\text { T2 In 1963, the company } \\
\text { faced with the difficulties } \\
\text { of growing in the State of } \\
\text { Sonora moved to the state } \\
\text { of Sinaloa, but the } \\
\text { government decrees a } 10 \% \\
\text { tax on egg introductions } \\
\text { from other productive } \\
\text { regions of the country. } \\
\text { T3 Transnational } \\
\text { companies are their main } \\
\text { competitors. } \\
\text { T4 During the period } 1994 \\
\text { to 2004, export earnings } \\
\text { remained marginalized. } \\
\text { T5 Between 1996 and } \\
\text { 2004, pig meat had } \\
\text { experienced greater } \\
\text { consumption, due to the } \\
\text { increase in imports in the } \\
\text { national supply. }\end{array}$ \\
\hline
\end{tabular}

Table 1 Strengths, Opportunities, Weaknesses and Threats (SWOT) for Grupo Bachoco, S.A.B de C.V.

Source: own elaboration with data from (Ceruti, M.; Hernández, M. C.; Marichal, C., 2010) 


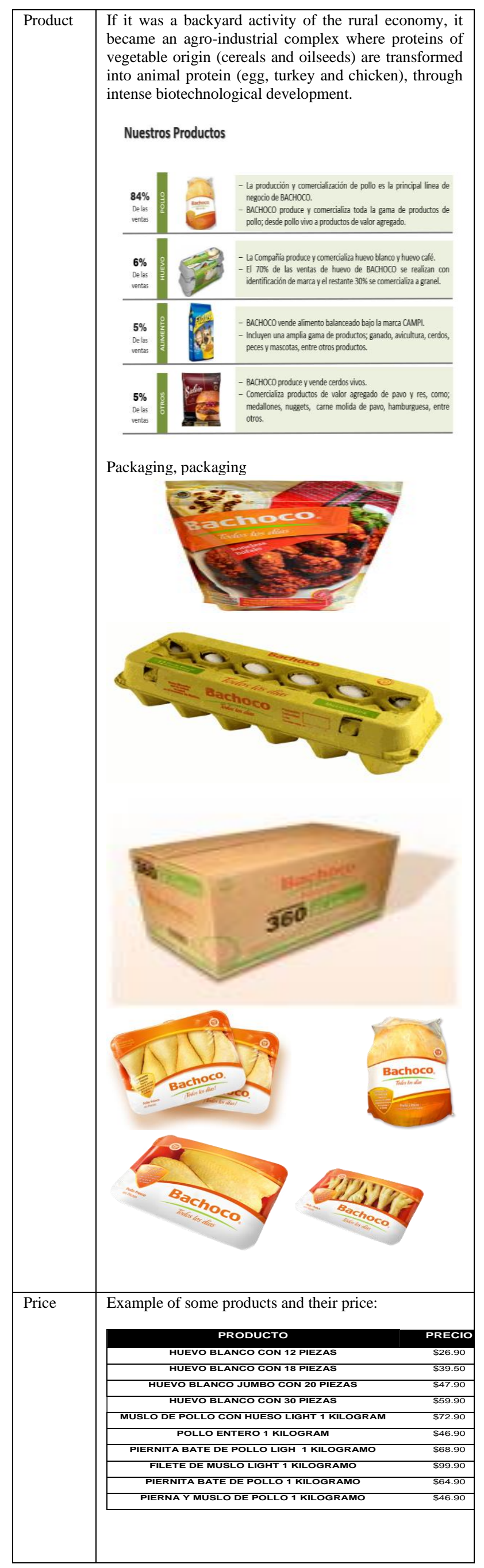

ISSN-On line: $2524-2008$

RINOE $^{\circledR}$ All rights reserved.

\begin{tabular}{|c|c|}
\hline Square & 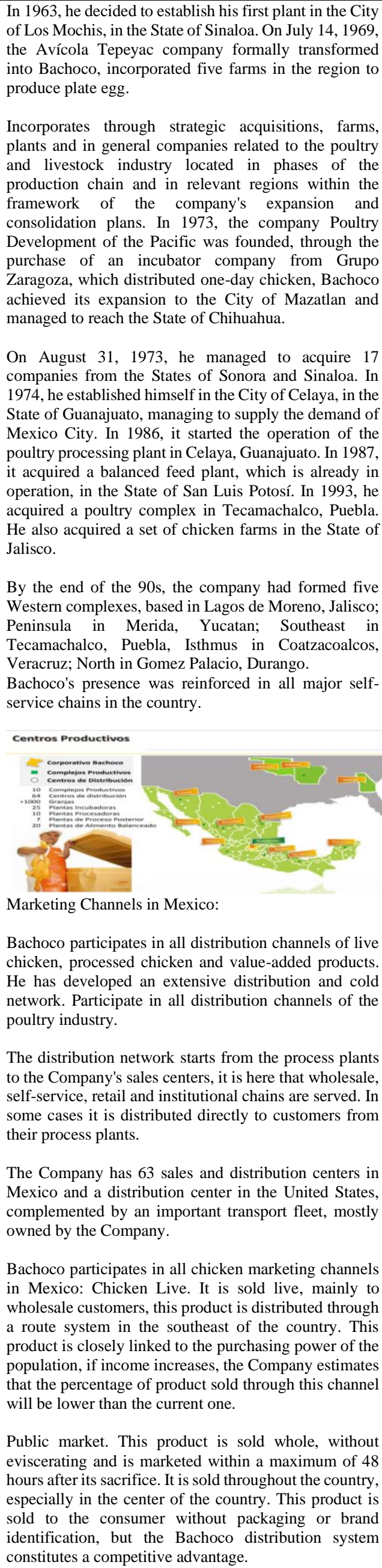 \\
\hline
\end{tabular}




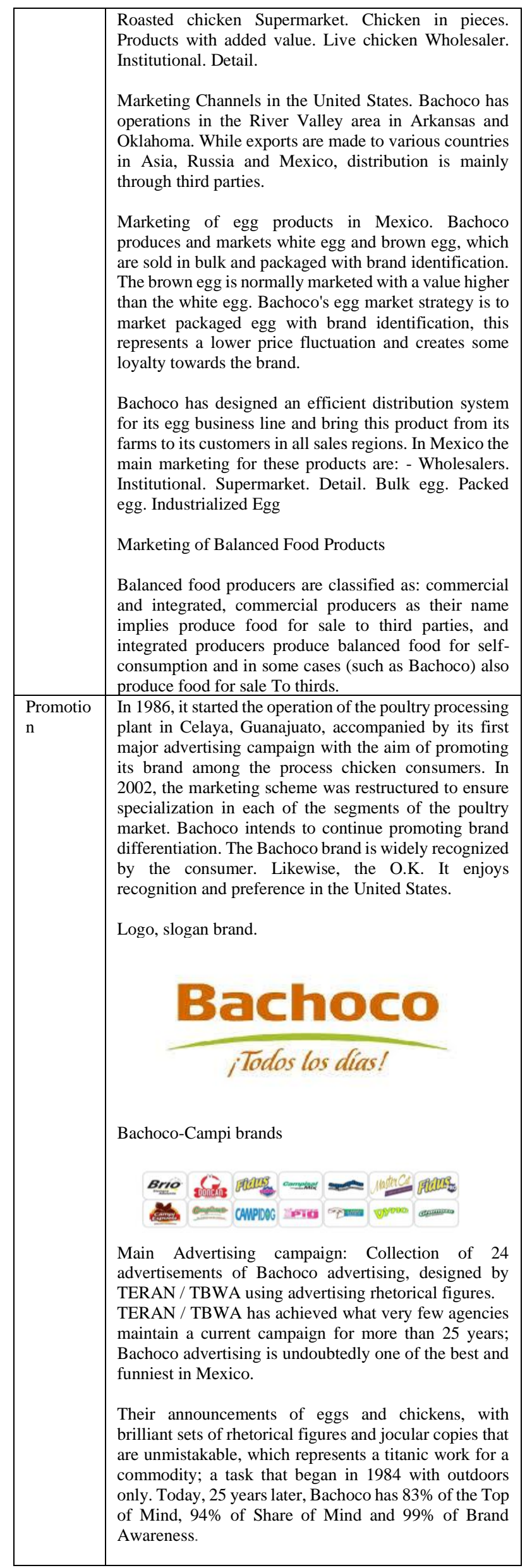

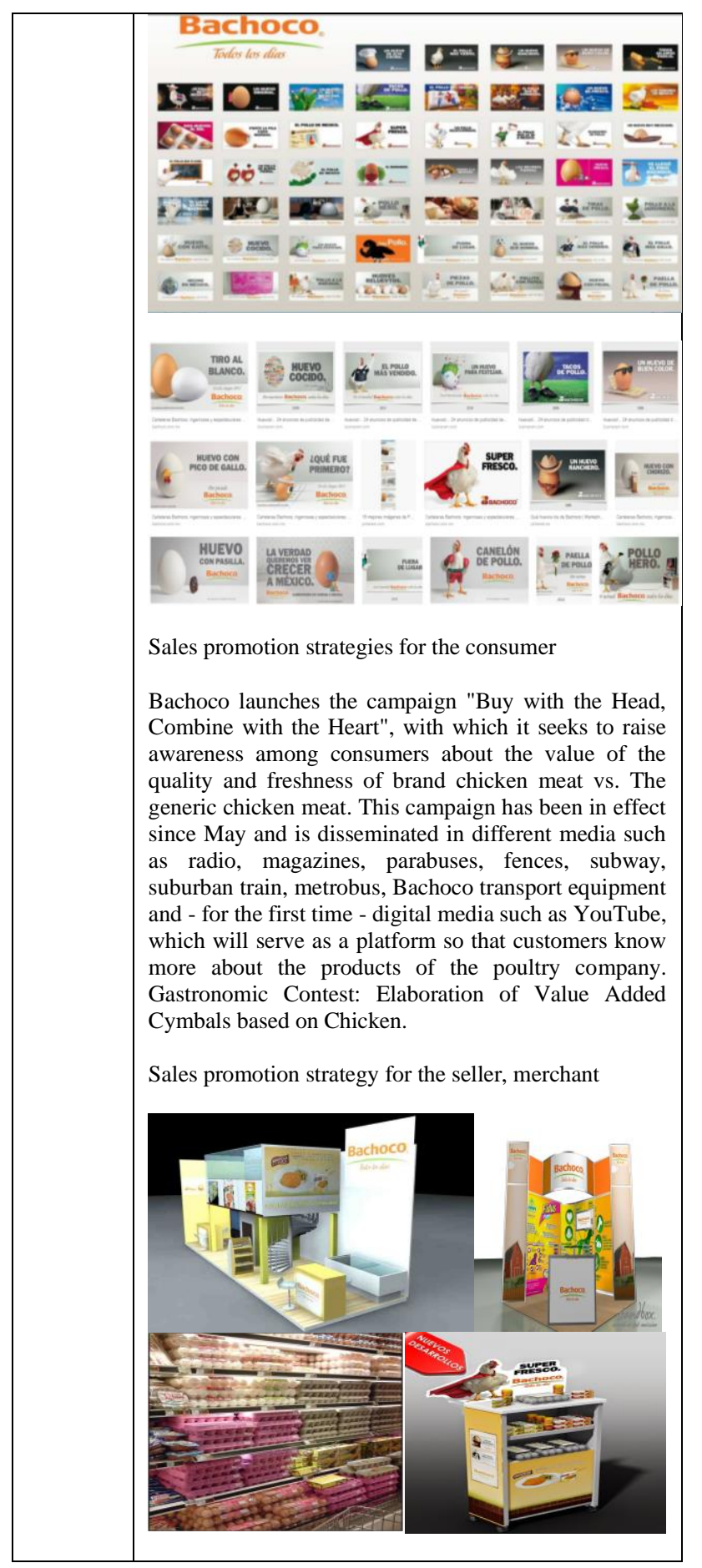

Table 2 El Mix Marketing de Grupo Bachoco, S.A.B de C.V.

Source: Own elaboration with data from (Ceruti, M .; Hernández, M. C .; Marichal, C., 2010). Imágenes de https://corporativo.bachoco.com.mx/wpcontent/uploads/2016/11/Presentaci\%C3\%B3nCorporativa-Web_2-3T16-E.pdf. Bachoco, Annual Report, several years 


\begin{tabular}{|c|c|}
\hline Strengt & Opportun \\
\hline $\begin{array}{l}\text { S1. High technology in } \\
\text { production. } \\
\text { S2 Innovation of new } \\
\text { products. } \\
\text { S3 Own resources before } \\
\text { the contraction of } \\
\text { financial resources. } \\
\text { S4 Renewal in the } \\
\text { technological } \\
\text { infrastructure. } \\
\text { S5 Technological update }\end{array}$ & $\begin{array}{l}\text { O1. Scientific advances in } \\
\text { the field of chemistry. } \\
\text { O2 Expand productivity. } \\
\text { O3 Impact on the transport } \\
\text { sector. } \\
\text { O4 Creation of new } \\
\text { products. } \\
\text { O5 Market positioning. }\end{array}$ \\
\hline Weaknesses & Threats \\
\hline $\begin{array}{l}\text { W1 Price increase } \\
\text { W2 Market competition } \\
\text { W3 Absorption of brands } \\
\text { and competing } \\
\text { companies. } \\
\text { W4 Perishable product. } \\
\text { W5 Dependence on } \\
\text { suppliers. }\end{array}$ & $\begin{array}{l}\text { T1 Rival regions for their } \\
\text { productivity. } \\
\text { T2 Elevation } \\
\text { production costs. } \\
\text { T3 Lack of publicity } \\
\text { T4 Crisis in the world } \\
\text { economy. } \\
\text { T5 Unstable relationships } \\
\text { with the industry. }\end{array}$ \\
\hline
\end{tabular}

Table 3 Strengths, Opportunities, Weaknesses and Threats (SWOT) for Grupo Lala, S.A.B de C.V.

Source: own elaboration with data from Lala company reports, several years.

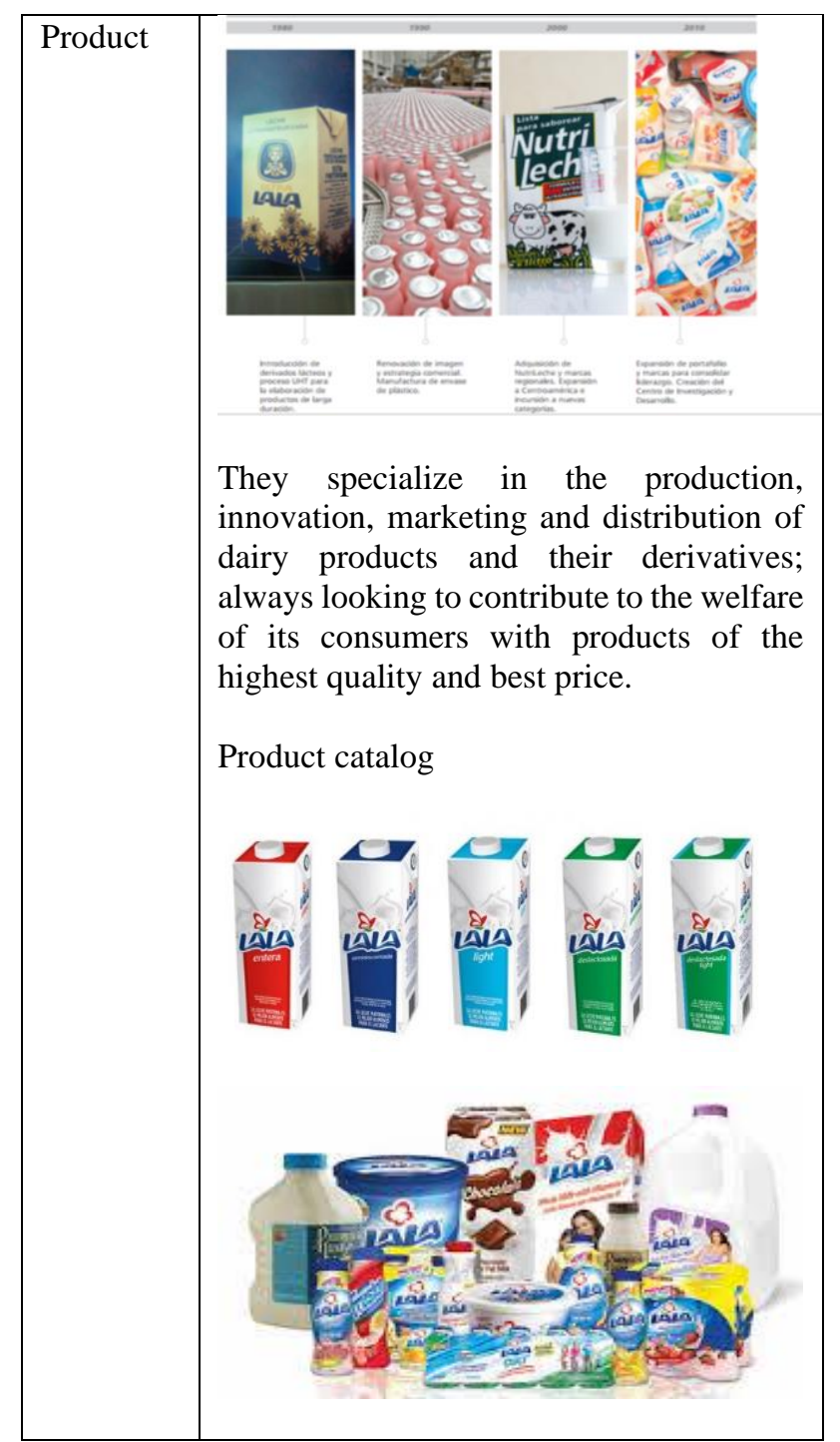

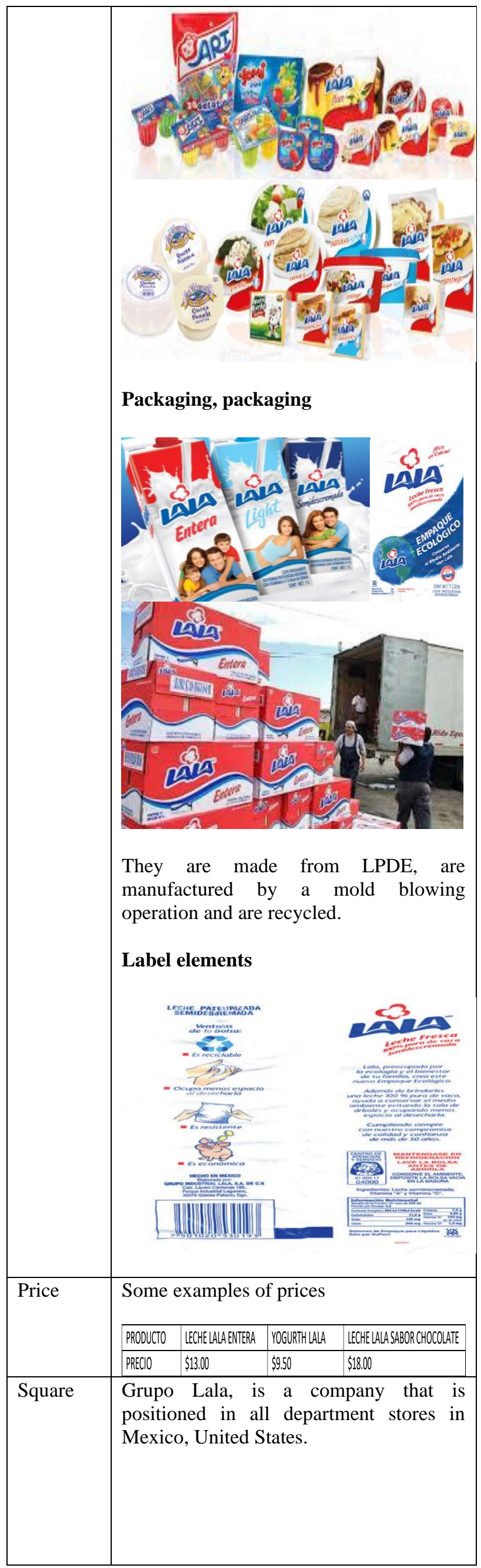

BALLESTEROS-AUREOLES, Alejandra, TLACUILO-GONZÁLEZ, José Antonio, Zavala-Ramírez, María Esther and Jiménez-Calvo, María de Lourdes. Market strategies in two major companies in Mexico: Bachoco and Lala. RINOE Journal - General Economics. 2019 


Promotio
Lala is a company focused on offering
quality and nutrition in its products, thus
providing a balanced and healthy
alternative to Mexican families; With rich
and healthy products.
If you want to know more about
everything that the Lala Group offers and
its latest releases, just periodically review
the online catalog of Lala and keep up to
date with all its news and promotions.
You can also follow them on their social
networks such as Facebook, Twitter and
Instagram, so you will be the first to know
the incredible offers and promotions that
Lala is always launching to meet the needs
of her most loyal followers.

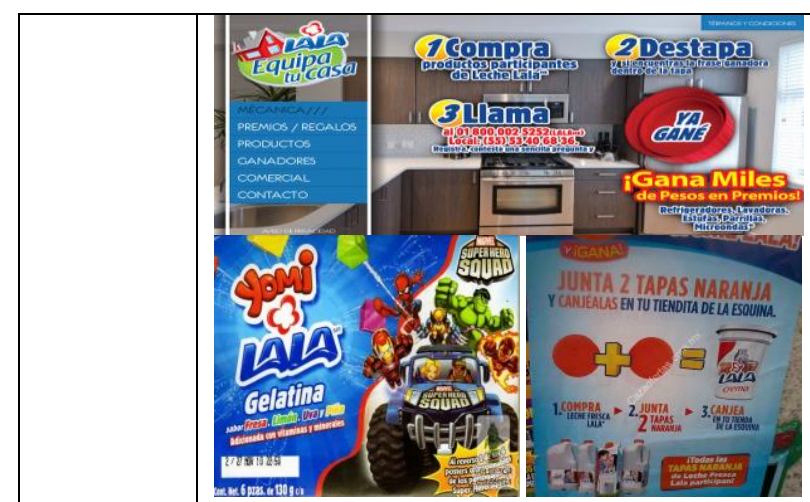

Estrategias de promoción de ventas para el distribuidor
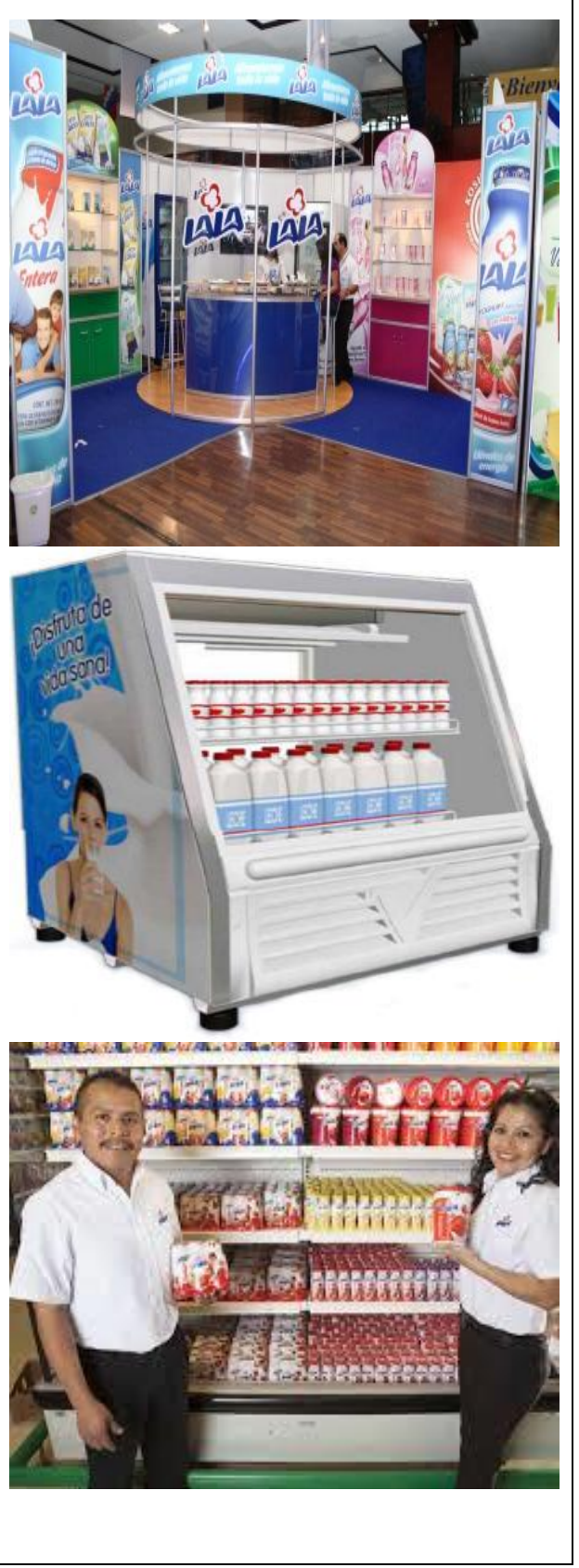


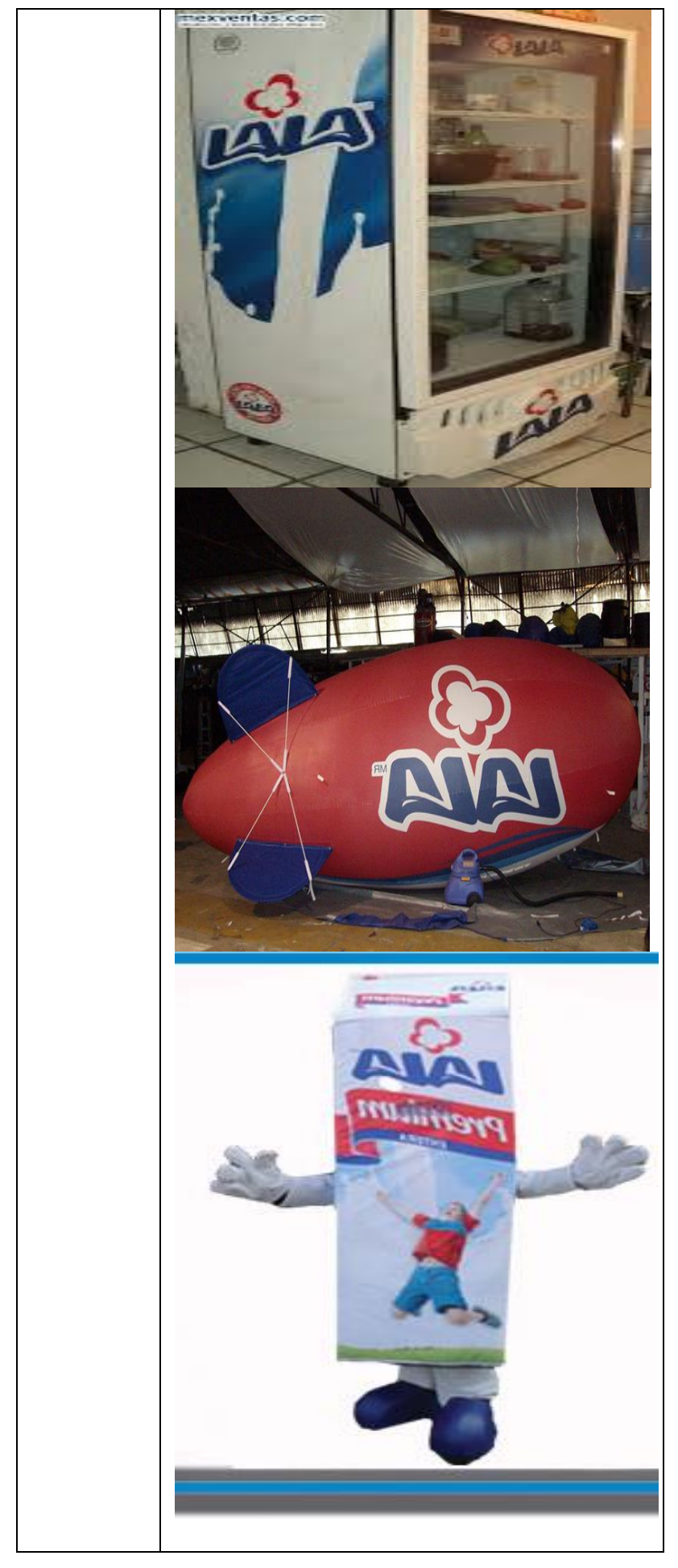

Table 4 The Mix Marketing of Grupo Lala, S.A.B de C.V. Source: own elaboration with data from Lala company reports, several years. (Ceruti, M.; Hernández, M. C .; Marichal, C., 2010).

\section{References}

AMA. (2019). AMA. Obtenido de https://www.ama.org/

Bachoco, I. (2017). Informe Anual. Obtenido de https://corporativo.bachoco.com.mx/wpcontent/uploads/2018/04/Informe-Anual-a-laBMV.pdf
Canedo, L. E., \& Barajas, M. J. (5 al 7 de mayo de 2004). El Mix-Marketing Como Elemento Estratégico En La Empresa: Caso Cervecería Cuauhtémoc Moctezuma S. A. De C.V. De Morelia, Michoacán, México. Memlorias del Congreso Acacia. Acapulcp, Guerrero, México. Obtenido de https://docs.google.com/viewerng/viewer?url=h ttp://gitmexico.com/acacia/busqueda/pdf/18226_Edmundo_Canedo_L__pez.pdf

Ceruti, M.; Hernández, M. C.; Marichal, C. (2010). Grandes empresas y grupos empresariales. México: Plaza y Valdés.

Fischer, L., \& Espejo, C. J. (2017). Mercadotecnia. México: Mc Graw Hill.

Lala, G. (2018). Informe Anual. Obtenido de https://www.lala.com.mx/pdf/docs/reportesbols a/anuales/Reporte_anual_2018.pdf

Mercado, S. (2008). Mercadotecnia estratégica. México: Instituto Mexicano de Conatores Públicos (IMCP).

Münch, L., Sandoval, P., Torres, G., \& Ricalde, E. (2012). Nuevos fundamentos de mercadotecnia. México: Trillas. 